\title{
Evaluation of Urban Bus Transport Failure in Gujranwala City of Pakistan
}

\author{
MUHAMMAD WAQAR ASLAM*, AND ZAHARA BATOOL** \\ RECEIVED ON 01.02.2016 ACCEPTED ON 11.05.2016 \\ ABSTRACT
}

\begin{abstract}
This research work has evaluated the performance of urban public bus transport service operating in Gujranwala city of Pakistan. The assessment has been made in terms of financial viability, bus condition, operational performance and user perception. Based on the data requirements, various traffic/transport surveys were conducted including Passenger Boarding and Alighting Survey, Bus Count Survey, Bus Inspection Survey, Illegal Operations Survey and Public Transport User Interview Survey in consultation with concerned department/agencies. Field surveys were also conducted to get input from passengers and local people.
\end{abstract}

Initial investigation informed that out of four operational bus routes, only two routes are profitable. The overall bus operation is running in loss (only $0.3 \%$ net profit). It has barely any profit for the bus operator against its investment thereby making the urban bus operation financially non-viable. The whole revenue flow is dependent on passenger ticketing revenue only. Around $35 \%$ of the buses are in poor condition with major issues of quality of tyres, no speedometer, worse condition of seats, floor and ceiling, and display of route. Illegal operation of Qingqis/Rickshaws (as para-transit mode) along the bus routes is also decreasing the revenue by capturing the passenger volume. According to passenger opinion analysis, around $55 \%$ of the passenger are not satisfied with the service quality and prefer other modes of transport. Their major concerns are absence of facilities for disables and bus stops, bus seating and standing capacity, poor bus condition and pick pocketing. Collectively, these factors are contributing towards the failure of bus public transport in Gujranwala city.

Key Words: Public Transport, Urban Bus, Performance Evaluation, Gujranwala.

\section{INTRODUCTION}

Transportation facilities are deemed as backbone for the socio-economic development of a country. A country cannot thrive if its transportation facilities are not up to the mark. Scarcity of transport facilities bodes ill for the progress of a country and its repercussions can be felt in every field of life. Transport systems are a very important aspect in the lives of people who live in cities as it provides mobility and access to most activities, but many transport systems are beginning to threaten the very livability of the cities they serve [1].

* Traffic Engineering \& Transport Planning Agency, Lahore Development Authority, Lahore.

** Department of Transportation Engineering \& Management, University of Engineering \& Technology, Lahore.

Mehran University Research Journal of Engineering \& Technology, Volume 36, No. 3, July, 2017 [p-ISSN: 0254-7821, e-ISSN: 2413-7219] 
With rapid urbanization and economic growth, motorization has been accelerating in cities in developing countries. For example, in the Asian region, the number of motor vehicles per one thousand people has more than tripled in the past 30 years. Owning a private car or a motorized two-wheeler is a major aspiration for people in these cities, in particular, where public transport service is often inadequate and unsafe [2]. The introduction of an efficient public transport can decrease these ascendant problems in the developing world's largest cities.

For an optimal working of any transport service in a city its evaluation and monitoring are the two most important factors. Stable and profitable revenue flows are the biggest challenges in transit services especially within the realm of public transport in larger cities. In order to raise more revenue from this sector, it is vital to introduce an optimal level of service within the sector and it is expected that alternative revenue sources can be generated this way [3].

Evaluation of urban transport can be measured in terms of benefits which can be viewed in different ways, and it is essential to distinguish between these approaches. Much of the debate about benefits stems from the chosen point of view. Three common viewpoints are financial, economic, or political. But the financial evaluation is most important one when it comes to fruitful and sustainable operation of public transport [4].

A financial viewpoint includes only those benefits that can be recovered as income. Benefits are those things that contribute to the rate of return on the investment in transit. Returns (benefits of transit) should occur directly to the agency to pay the expense of providing service. There are many factors which adversely effects the financial sustainability and viability of urban transport system. One of the common factors these days is the regular use of Para-transit modes like Qingqi/Rickshaws which has a negative impact on the safe, efficient, timely and environment friendly movement of public transport. It also effects the revenue generation process by capturing the passenger volume thereby resulting in revenue loss and making it financially unviable in absence of some subsidy policy or enforcement by the Government Agencies [5].

For performance evaluation of bus service, condition of buses is also vital for successful bus operations as poor conditions of buses will compel the passengers to shift to other available modes of transport which will result in loss of passenger revenue. In addition, input of daily commuters can also contribute a lot in the improvement of urban transport system as they are the end user of this service. Thus, passengers satisfaction is necessary for sustainable operation of public transport.

\section{STUDYAREA-GUJRANWALACITY}

To carry out the research, Gujranwala is selected as model city because it is the only city after Lahore which has urban public bus transport network. No previous study has been conducted to analyze and assess the operation and performance of these buses. It is an industrial city in the north east of the Punjab province with a population of approximately 2,723,009. The average annual growth rate of the city is $3.79 \%$ and population density of 939 persons/kilometer square. It shares borders with several small cities, towns and villages including Ghakhar Mandi, Alipur Chatha and Kamonke. Due to extensive road and rail links, the city has flourished within the manufacturing and agricultural markets. The city is on the GT (Grand Trunk) Road, which allows logistical connections to the provincial capitals such as Peshawar and Lahore and also to the capital of Pakistan, Islamabad [6] . It is estimated that 640,423 s vehicles are registered till June 2014 within the Gujranwala district which include 24,761 Cars, Jeeps and Station Wagons, 567,197 motorcycles and scooters,

Mehran University Research Journal of Engineering \& Technology, Volume 36, No. 3, July, 2017 [p-ISSN: 0254-7821, e-ISSN: 2413-7219] 
1393 trucks, 2046 Mini Buses/Buses/Flying/Luxury Coaches, 5414 Pickups/Delivery vans, 1941 Taxis, 6,339 Auto rickshaws, 30,988 tractors and 344 other vehicles [7]. Fig. 1 shows the map of Gujranwala city along with currently plying bus routes.

\subsection{Public Transport in Gujranwala}

Eight stage carriage routes were defined for Gujranwala in Punjab Gazette dated June 2006. Table 1 shows the defined routes with their origin, destination and current status. Presently "City Tour" is the only bus company providing urban transport services in the city. They have a fleet of 83 buses which links Daska, Kamonki, Wazirabad, Gakkhar and WAPDA town with the Gujranwala city. These buses are the main source of passenger movement in the city. The company is allowed to operate along eight specified routes, however, only four routes (B1, B2, B4 and B5) are currently in operation due to certain limitations and constraints like merging and overlapping of routes, inadequate right of way, low vertical clearance at certain locations, sharp turns and some political hindrances. The only source of income for operation of these buses is the revenue gained from passenger ticketing.

Beside these urban buses, the only other and major transport mode for intra-city travel of people is Qingqis which are running as para-transit mode. These Qingqis have no specified routes and is preferred mode of transport by locals due to its flexibility and availability for short distance travel or where there is no access by the buses. Around 16,000 passengers are using Qingqis/ Rickshaws for their daily commuting along these bus routs.

\section{PERFORMANCE EVALUATION INDICATORS}

Performance indicators are powerful tools for monitoring and improving transit service. While there are many possible indicators that can be used, typically a small subset is used on a regular basis to monitor the important aspects of transit system performance. The

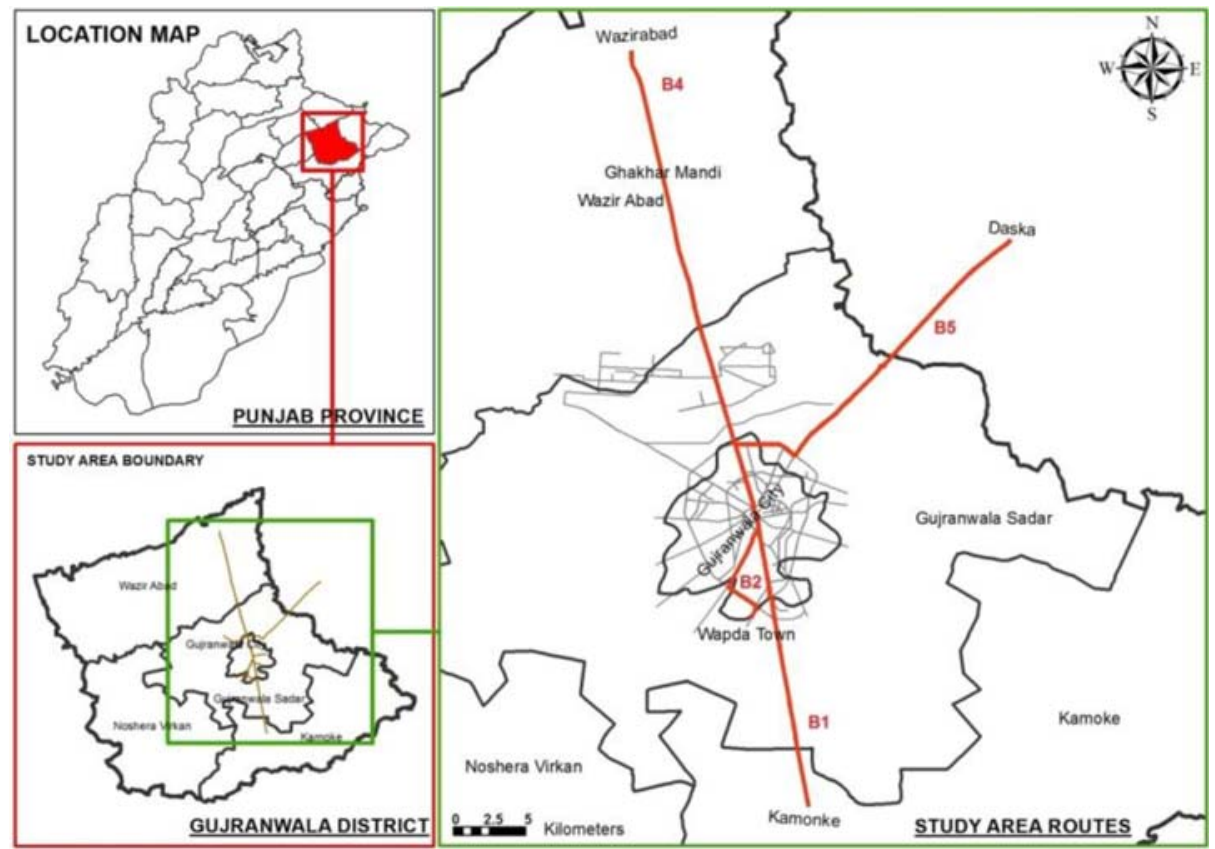

FIG. 1. STUDYAREAMAPALONG WITHOPERATIONAL BUS ROUTES(SOURCE: AUTHOR)

Mehran University Research Journal of Engineering \& Technology, Volume 36, No. 3, July, 2017 [p-ISSN: 0254-7821, e-ISSN: 2413-7219] 
approach for using indicators to assess performance is relatively easy to implement. Some of the indicators used to evaluate service performance are readily available in most systems and others can be collected and analyzed as conditions warrant.

In a system as complex as transit, there can be hundreds of measures to assess performance. However, experience has shown that in many situations a relatively small number of measures can be used effectively [8]. Following flowchart (Fig. 2) shows both financial and non-financial indicators used around the world to check the financial viability of an urban transport network. These evaluation parameters have been applied in varies cities around the world including cities of America, India, Bangladesh and Srilanka [9-10].

\section{RESEARCH METHODOLOGY}

\subsection{Data Collection}

The data like operational and maintenance costs, salary of staff and the specified route along with their length and location of bus stops has been collected/gathered from District Regional Transport Authority Gujranwala and City Tour bus company. Whereas the passenger ridership, condition of buses characteristics of bus routes and public opinion has been obtained from different traffic/transport surveys like Bus Boarding and Alighting Survey, Bus Condition Survey, Bus Count Survey, Illegal Operations Survey and Public Transport User Interview Survey.

TABLE 1. SPECIFIED URBAN ROUTES IN GUJRANWALA CITY

\begin{tabular}{|c|c|c|c|}
\hline Rout No. & Origin and Destination & Length of Route $(\mathrm{km})$ & Status \\
\hline B1 & Kamonki to Aziz Cross & 30 & Operational \\
\hline B2 & Chan Da Qilla to Gakhar & 24 & Operational \\
\hline B3 & Aziz Cross (Pindi Bye-pass) to WAPDA Town & Non-Operational \\
\hline B4 & Sheikhupura Morr to Wazirabad Railway Station & 34 & Operational \\
\hline B5 & Daska to Gulshan Iqbal Park Mor & 22 & Operational \\
\hline B6 & Behari Colony to Rahwali Cantt & - & Non-Operational \\
\hline B7 & Zamindara Stand to Dharam Kot Chowk & - & Non-Operational \\
\hline B8 & Tatley Aali to Aziz Cross & - & Non-Operational \\
\hline
\end{tabular}

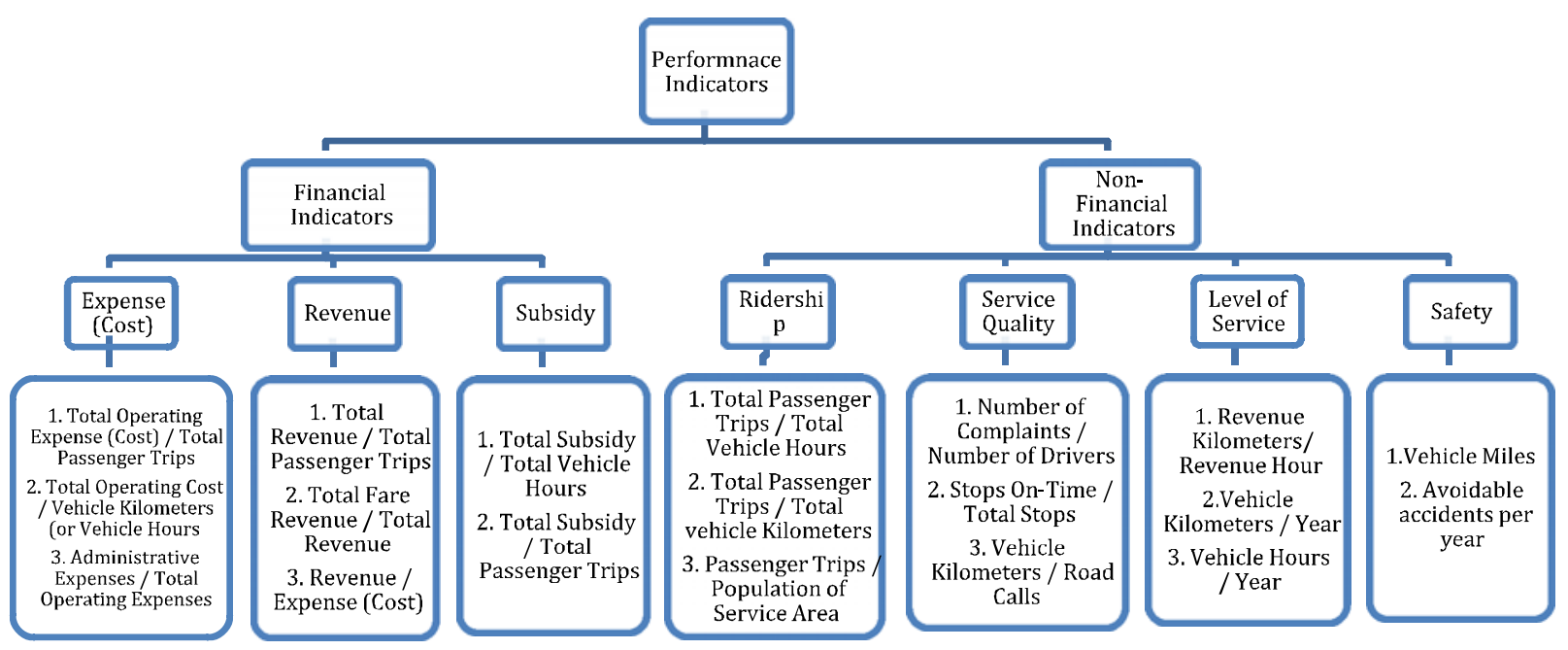

FIG. 2. PERFORMANCE EVALUATION INDICATORS [8] 


\subsection{DataAnalysis}

The collected data is coded, validated against the data provided by the bus company, digitized and analyzed using softwares like ArcGIS 10, Excel 2007 and SPSS 19. ArGIS 10 is used to draw to maps of each route along with the location of bus stop and other characteristics. Excel 2007 is for coding of data and cost benefit analysis of each route whereas SPSS 19 is used for analysis of user interview survey.

The basic data for the performance evaluation has been analyzed and aggregated to calculate the required measures. Before aggregating the raw data into the performance indicators, the time period of one year has been established for the analysis and the operational level being considered. The recommendations are then made on the basis of the analysis results.

\section{RESULTS AND DISCUSSION}

\subsection{Characteristics of Operational Bus Routes in Gujranwala}

The frequency of buses observed, average headway on each route, total number of trips per day, and total passenger volume travelled through the buses are given in Table 2. These results were achieved from bus count survey conducted at GBS (General Bus Stand) in both directions.

\subsection{Cost Analysis of Operational Bus Routes in Gujranwala City}

Operating cost on each bus route is calculated on the basis of some assumptions and the financial data obtained from the site visit and City Tour office whereas revenue on each route has been calculated from boarding \& alighting survey performed for whole day and cross checked with available ticketing data.

For B1, average cost per trip is Rs.1,207/- against average revenue of Rs.1,221/- with a marginal profit of Rs. 14/- per trip. B4 is the most profitable route with average cost per trip of Rs.1,535/- against average revenue of Rs. 1,679/- and profit of Rs. 144/- per trip. Where route B-2 and B-5 are running in loss with average loss of Rs. 249/- and Rs. 93/- respectively against the average cost of Rs.1275/- and Rs. 1049/per trip and average revenue of Rs. 1026/- and Rs. 956/ - respectively. Table 3 shows average cost and revenue associated to each route along with their profit/loss per trip.

When the analysis is expanded for total cost and revenue per day on each route, it is observed that only route B4 is profitable (9\%) whereas the route B2 and B5 are running in total lose (20 and 9\% respectively). Route B1 is nearly running on breakeven with a profit of $1 \%$ only. The overall operation of the buses is not financially viable as the operator is not getting any profit for this investment thereby making the operator least interested to improve

TABLE 2. CHARACTERISTICS OF OPERATIONAL ROUTES

\begin{tabular}{|c|c|c|c|c|}
\hline Route No. & No. of Buses & Average Headway (Minutes) & Total No. of Trips/Day & Passenger Volume/Day \\
\hline B1 & 35 & 8 & 235 & 18,051 \\
\hline B2 & 14 & 19 & 118 & 6,016 \\
\hline B4 & 22 & 10 & 198 & 17,435 \\
\hline B5 & 10 & 24 & 73 & 5,378 \\
\hline
\end{tabular}

Mehran University Research Journal of Engineering \& Technology, Volume 36, No. 3, July, 2017 [p-ISSN: 0254-7821, e-ISSN: 2413-7219] 
the quality of service. Table 4 shows the summary of profit/loss on each route and in total.

It is in practice, that the authority set fare level of service on the basis of operating cost and bus ridership. Thus, more ridership is desirable by all operators to enhance profit/yield from fixed resources. Revenue is primarily derived through daily sales of passenger tickets only.

Some of the reasons associated with the losses on these operational bus routes are overleaping of bus routes, improper headway between the buses during peak and off-peak hours and fleet size mismanagement on each route. These losses can be minimized by adjustment of fleet size on each route based on the passenger volume and increasing/decreasing headways in specific time periods to cater the varying demand.

\subsection{Illegal Para-Transit Operations}

Illegal para-transit transport operation is the major issue that directly affects the operations and sustainability of legally operating bus public transport. The illegal operations survey was conducted to determine number of illegal boarding along GT Road, Gujranwala through Qingqi rickshaws and modified illegally designed Auto rickshaws. However, it was not possible to carry-out assessment along the full length of GT road due to limited resources. Fig. 3 shows the selected key locations to estimate the illegal boarding trend in the city and their percentage share.

The results from illegal transport assessment survey have indicated that more than sixteen thousand passengers daily use illegal transport along GT Road between Chanda Qilla and Pindi Bypass. Majority of passengers using para-transit transport; board between Sheikhupura Morr and Gondlanwala due to markets and shopping arcades. Fig. 4 shows the total number of passengers boarding along GT Road.

\subsection{Bus Condition Survey}

There are total 83 buses in the fleet serving as public transport. 70 buses have diesel engine whereas 13 are running on CNG engine. Fig. 5 shows percentage distribution of condition of buses in each category.

TABLE 3. COST AND REVENUE ON EACH ROUTE

\begin{tabular}{|c|c|c|c|c|c|c|c|}
\hline Route No & No of Buses & $\begin{array}{c}\text { Average Headway } \\
\text { (Minutes) }\end{array}$ & $\begin{array}{c}\text { Total No of } \\
\text { Trips/Day }\end{array}$ & $\begin{array}{c}\text { Passenger } \\
\text { Volume/Day }\end{array}$ & $\begin{array}{c}\text { Average } \\
\text { Cost /Trip }\end{array}$ & $\begin{array}{c}\text { Average } \\
\text { Revenue /Trip }\end{array}$ & $\begin{array}{c}\text { Profit/Loss /Trip } \\
\text { (PKR) }\end{array}$ \\
\hline B1 & 35 & 8 & 235 & 18,051 & 1,207 & 1,221 & 14 \\
\hline B2 & 14 & 19 & 88 & 5,580 & 1,275 & 1,026 & -249 \\
\hline B4 & 22 & 10 & 198 & 17,435 & 1,535 & 1,679 & 144 \\
\hline B5 & 10 & 24 & 78 & 4,286 & 1,049 & 956 & -93 \\
\hline
\end{tabular}

TABLE 4. SUMMARY OF BUS ROUTES PROFIT / LOSS

\begin{tabular}{|c|c|c|c|c|c|}
\hline Route No & $\begin{array}{c}\text { Total No of } \\
\text { Trips/Day }\end{array}$ & $\begin{array}{c}\text { Total Cost/Day } \\
\text { (PKR) }\end{array}$ & $\begin{array}{c}\text { Total Revenue/Day } \\
\text { (PKR) }\end{array}$ & $\begin{array}{c}\text { Total Profit/Loss/Day } \\
\text { (PKR) }\end{array}$ & $\begin{array}{c}\text { Total Profit/Loss } \\
\text { (\%) }\end{array}$ \\
\hline B1 & 235 & 283,645 & 286,997 & 3352 & 1 \\
\hline B2 & 88 & 112,200 & 90,272 & -21928 & -20 \\
\hline B4 & 198 & 303,930 & 332,423 & 28493 & 9 \\
\hline B5 & 78 & 81,833 & 74,555 & -7279 & -9 \\
\hline Total & 599 & 781,608 & 784,247 & 2,639 & 0.3 \\
\hline
\end{tabular}

Mehran University Research Journal of Engineering \& Technology, Volume 36, No. 3, July, 2017 [p-ISSN: 0254-7821, e-ISSN: 2413-7219] 


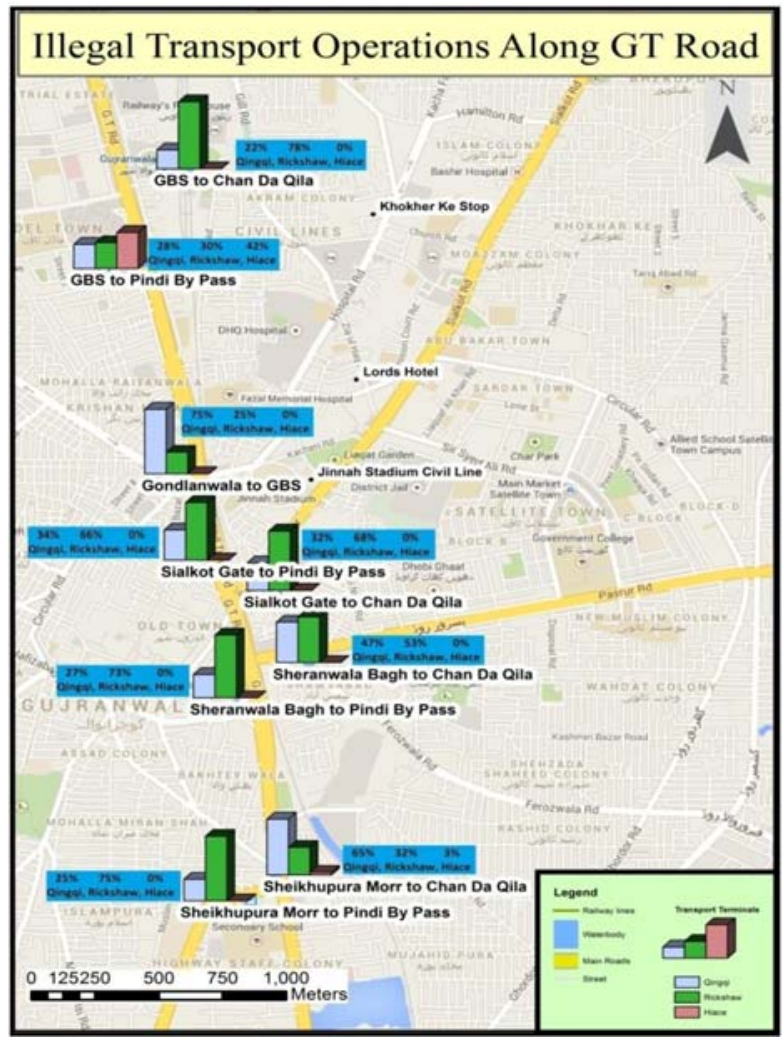

FIG. 3. ILLEGAL TRANSPORT OPERATIONS ALONG GT ROAD

\subsection{Public Transport User Interview Survey}

The user opinion and characteristics are important to introduce any facility or make improvements to the existing condition. For this purpose, a PTUI (Public Transport User Interview) survey was conducted with a sample size of 386 users using random sampling.

The analysis shows the perception of the public regarding the current services of public transport. Majority reported little or no facilities for the disabled persons, poor seating and standing capacity of buses, inadequate bus timings, and adverse bus stops facilities. Most of the respondents are not satisfied with the condition of the buses, safety while travelling and travel time of the trips. In general citizens are dissatisfied with the quality of public transport services which promote the use of other transport modes like

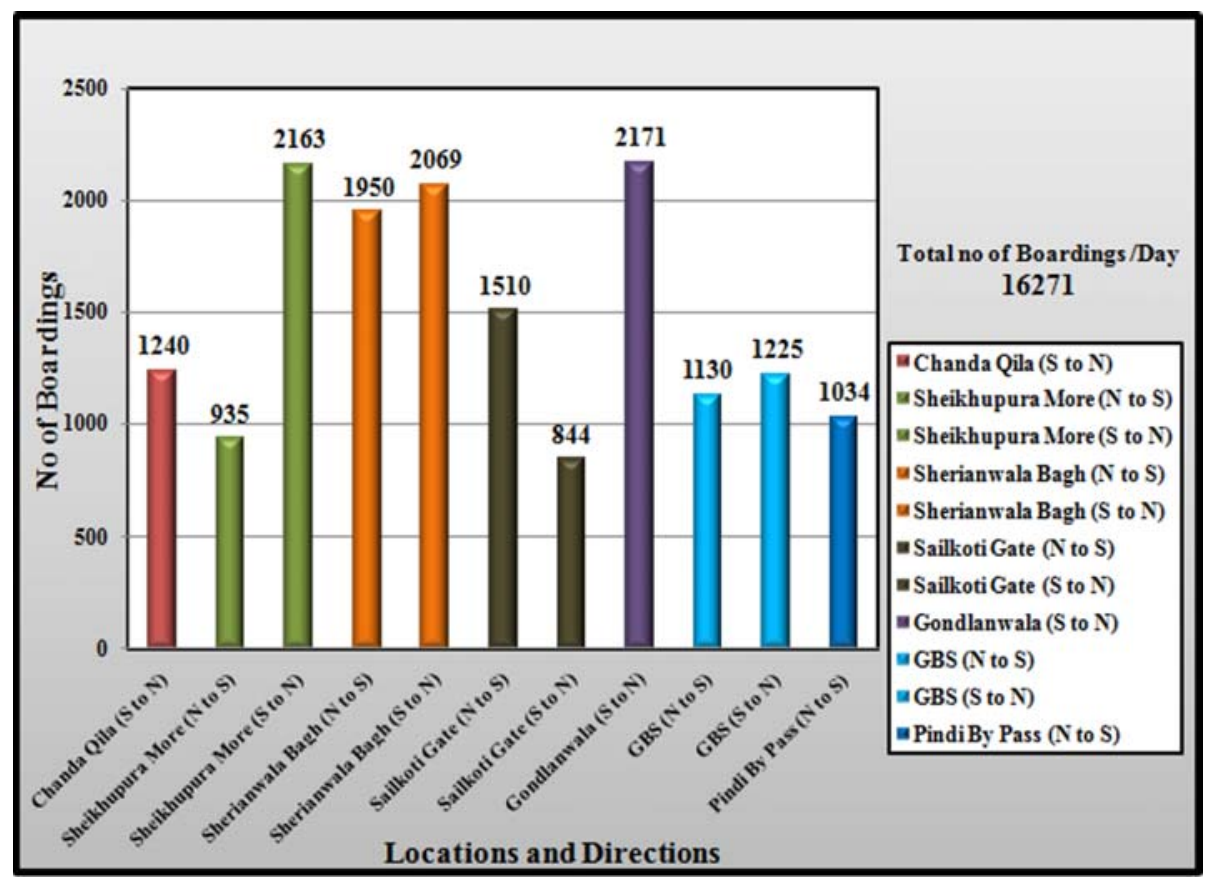

FIG. 4. ILLEGAL BOARDING AT DIFFERENT LOCATIONS ALONG GT ROAD

Mehran University Research Journal of Engineering \& Technology, Volume 36, No. 3, July, 2017 [p-ISSN: 0254-7821, e-ISSN: 2413-7219] 
Qingqi or Rickshaw particularly for short travel distance. Fig. 6 shows results of user opinion about public transport and facilities.

\subsection{Summary of the Research Findings}

Table 5 shows the summary of findings of this research work based on the analysis and results.

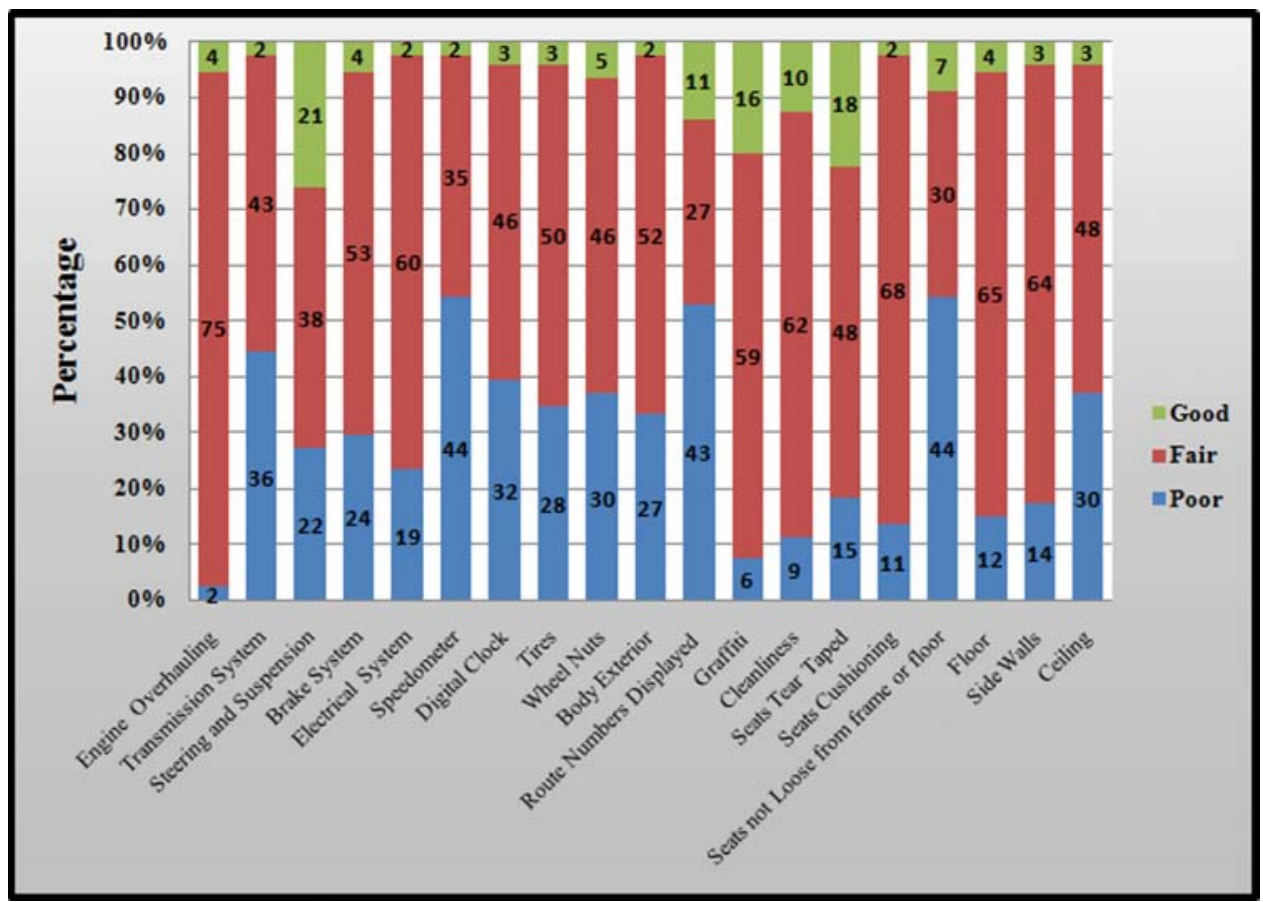

FIG. 5. BUS CONDITION SURVEY RESULTS

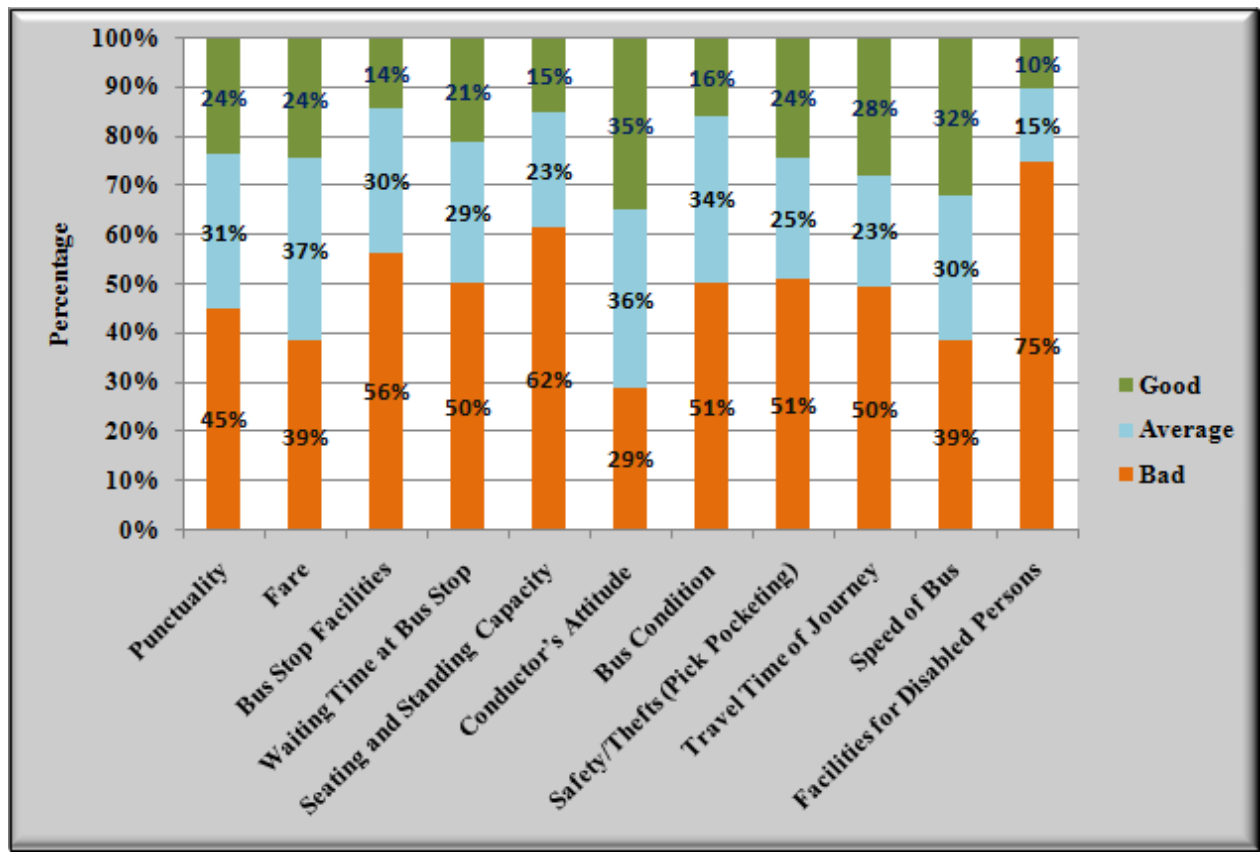

FIG. 6. USER OPINION ABOUT PUBLIC TRANSPORT AND RELATED FACILITIES 
TABLE 5. SUMMARY OF RESEARCH FINDINGS

\begin{tabular}{|c|c|c|c|}
\hline \multicolumn{4}{|c|}{ Financial Indicators } \\
\hline Indicator & Problem Identified & Reason & Solution \\
\hline Expense & Needless Expenses & $\begin{array}{l}\text { Improper headway and frequency of } \\
\text { buses and overlapping of bus routes }\end{array}$ & $\begin{array}{l}\text { Bus headways and fleet size on each } \\
\text { route can be adjusted during peak and } \\
\text { off-peak hours based on varying } \\
\text { passenger demand to reduce the } \\
\text { expenses. Route B- } 2 \text { and B- } 5 \text { can be } \\
\text { modified to reduce the overlapping. }\end{array}$ \\
\hline Revenue & $\begin{array}{l}\text { Reducing in revenue due to } r \\
\text { eduction in passenger volume }\end{array}$ & Illegal para-transit operations & $\begin{array}{l}\text { Adjustment of headways in peak } \\
\text { hours, improvement in condition of } \\
\text { buse s a nd enforc e me nt from } \\
\text { Government agencies regarding } \\
\text { operation of illegal para-transit modes } \\
\text { like Qingqi/rickshaws along the bus } \\
\text { routes. }\end{array}$ \\
\hline Subsidy & $\begin{array}{l}\text { Absence of operational subsidy } \\
\text { from the Government }\end{array}$ & $\begin{array}{l}\text { No allocation of funds by the } \\
\text { Government }\end{array}$ & $\begin{array}{l}\text { Output based operational subsidy } \\
\text { must be provided by the Government } \\
\text { as the revenue is solely dependent of } \\
\text { passenger ticketing and fare policy is } \\
\text { also controlled by Regional Transport } \\
\text { Authority to make the operation } \\
\text { financially viable. }\end{array}$ \\
\hline \multicolumn{4}{|c|}{ Non-Financial Indicators } \\
\hline Bus Condition & Poor maintenance of buses & $\begin{array}{l}\text { In absence of subsidy, where expenses } \\
\text { are greater than the revenue; the } \\
\text { operator does not care much about the } \\
\text { timely maintenance of buses }\end{array}$ & $\begin{array}{l}\text { Provision of output based subsidy } \\
\text { from Government so that the operator } \\
\text { will fo c us on o p e ration a nd } \\
\text { maintenance of buses rather than } \\
\text { saving his cost. }\end{array}$ \\
\hline Service Quality & $\begin{array}{l}\text { Fixed Headways } \\
\text { throughout the day }\end{array}$ & Improper fleet management & $\begin{array}{l}\text { Headways can be adjusted on each } \\
\text { bus route during specific time periods } \\
\text { to cater varying passenger demand. }\end{array}$ \\
\hline User Opinion & $\begin{array}{l}\text { Passenger dissatisfaction which } \mathrm{r} \\
\text { esults in shifting of passenger to } \\
\text { ther modes of transport }\end{array}$ & $\begin{array}{l}\text { No facilities for the disabled persons, } \\
\text { poor seating and standing capacity of } \\
\text { buses, improper bus headways, } \\
\text { adverse bus stops facilities and pick } \\
\text { pocketing }\end{array}$ & $\begin{array}{l}\text { Provision of facilities for disables, } \\
\text { display of bus routes, prop er } \\
\text { maintenance of buses, safety inside } \\
\text { buses and adjustment of headways } \\
\text { can attract more passenger volume } \\
\text { thereby increasing the revenue. }\end{array}$ \\
\hline
\end{tabular}

\section{CONCLUSIONS}

From the analysis of current situation of bus routes it is concluded that route B1 is almost at breakeven with net profit of $1 \%$. B2 is in loss; this is mostly due to merging of two routes and overlapping of merging route with other bus routes. The bus route B4, is the most profitable route with $9 \%$ net profit. B5 is also in loss due to this partially shared route with other public service vehicles and low headway gap. When the whole scenario is expanded for overall bus operation per day it is evident that the current operation of urban buses is not financially viable with a bare marginal net profit of $0.3 \%$ against the recommended profit gain of $15-20 \%$. Furthermore, poor condition of the buses are also encouraging the passengers to shift to other transport modes like illegal para-transit modes of Qingqis/
Rickshaws particularly for short travel distance thereby resulting in loss inform of decrease in passenger revenue. Around 16,000 passengers are using Qingqis/ Rickshaws for their daily commuting along GT road.

It is also concluded that the performance of public bus transit in Gujranwala has also declined due to dissatisfaction of passengers from the quality of transport service thereby encouraging them to adopt other modes of transport. Overall, all these factors are contributing in the failure of successful and sustainable bus operations in Gujranwala city.

\section{RECOMMENDATIONS}

Based on the analysis and input from passengers and local people, following are some recommendations can 
be adopted to improve revenue flows and improve public transport performance in Gujranwala city:

(i) Adjust headway at certain times on specific routes to cope with passenger demand.

Penalizing the commuters for travelling without tickets as approved under the Motor Vehicle Act 1965.

Output based operational subsidy must be provided by the Government sector inorder to make bus operations in Gujranwala city financially viable; which in result will make the operator interested in improving the efficiency and service of bus operations.

(iv) The enforcement of the available acts and laws about illegal operations should be thoroughly implemented through traffic police, District Regional Transport Authority and Motor Vehicle Examiners to reduce revenue loss to bus operator.

(v) The improvement and construction of quality bus-stops at busy locations may attract more passengers towards urban transport.

(vi) Improved user information for example bus schedules, route information, bus arrival, \& departure time to build passenger confidence and attract passenger towards Public transport use.

(vii) The roadway infrastructure like bus stops, pedestrian underpasses/footbridges, bus lanes, footpaths, etc. should be constructed for passenger and public ease to promote public transport in the city.

(viii) A public awareness campaign should be launched regarding safety threats and hazards associated with Qingqi (Motorcycle) rickshaws and other illegal modes of transport causing pollution, congestion, safety issues and other chronic diseases.

\section{ACKNOWLEDGEMENTS}

Authors owe deep gratitude to all those who contributed substantially in completion and undertaking of this study. Authors are also thankful to District Regional Transport Authority Gujranwala, Transport Planning Unit (Transport Department, Punjab) and City Tour 'Bus Company' for providing all the required/necessary data, their valuable support and discussion during this study. We are also thankful to Dr. Tanvir Iqbal Qayyum, for this guidance throughout the whole research work.

\section{REFERENCES}

[1] IEA (International Energy Agency), "Bus Systems for the Future: Achieving Sustainable Transport Worldwide", International Energy Agency, Paris, 2002.

[2] United Nations Department of Economic and Social Affairs, "Shanghai Manual: A Guide for Sustainable Urban Development in the $21^{\text {st }}$ Century", China International Publishing Group, Beijing, 2011.

[3] Masood, T., Khan, M.A., and Naqvi, A.H., "Transportation Problems in Developing Countries Pakistan. A Case-in-Point”, IJBM, Volume 6, No. 11, 2011.

[4] Vuchic, V.R., "Urban Transit Systems and Technology", Wiley; Chichester: John Wiley [Distributor], Hoboken, NJ, 2007

[5] Ryus, P., “A Methodology for Performance Measurement and Peer Comparison in the public Transportation Industry”, TCRP Report 141. Transportation Research Board, Washington, DC, 2010

[6] Gujranwala. Wikipedia.org. [Online] Wikimedia Foundatio, [Cited: July 21, 2015.] http://en.wikipedia.org/ wiki/Gujranwala.

[7] Punjab Bureau of Statistics, Punjab Development Statistics, Punjab Bureau of Statistics, Lahore, 2015.

[8] Bruun, E.C., "Better Public Transit Systems: Analyzing Investments and Performance", Second Edition, Routledge, New York, 2013.

[9] Gwilliam, K.M., "Cities on the Move”, A World Bank Urban Transport Strategy Review, World Bank, Washington, DC, 2002.

[10] Transit Cooperative Research Program, National Research Council (US), Transportation Research Board, Cambridge Systematics Inc, and Apogee Research, Inc. "Measuring and Valuing Transit Benefits and Disbenefits", TCRP Report, Volume 20, pp. 1073-4872, National Academy Press, Washington, DC, 1996.

[11] Telliford, G.T., "Public-Private Transportation Partnerships Around the World", Nova Science Publishers, New York, 2009. 